JURNAL AL BAYAN: JURNAL JURUSAN PENDIDIKAN BAHASA ARAB

p-ISSN 2086-9282 | e-ISSN 2549-1229

http://ejournal.radenintan.ac.id/index.php/albayan/index

\title{
The Characteristics Of Arabic Language Textbooks Of Madrasah Ibtidaiyah
}

\author{
Umi Machmudah ${ }^{1 *}$, Khuzaimah ${ }^{2}$, Mufidatus Sholihah ${ }^{3}$ \\ ${ }^{1}$ Prodi Pendidikan Bahasa Arab Universitas Islam Negeri Maulana Malik Ibrahim Malang, Indonesia \\ ${ }^{2}$ PPSP Al-Ishlahiyah, Malang, Indonesia \\ ${ }^{3}$ PPSP Al-Ishlahiyah, Malang, Indonesia
}

\section{Article History:}

Received : March 15 ${ }^{\text {th }}, 2019$

Revised : April 17 $17^{\text {th }}, 2019$

Accepted : May $13^{\text {th }}, 2019$

Published : June $1^{\text {st }}, 2019$

\section{Keywords: \\ Book; Hijaiyah; Skills; Organization}

*Correspondence Address:

machmudah@pba.uin-malang.ac.id

\begin{abstract}
This research aims to describe the various main angles that become potential which include: 1) Principles for preparing teaching materials, 2) Organization of teaching materials, 3) Language skills 4) Learning objectives and 5) Types of evaluations, which are applied in Arabic textbooks of Madrasah Ibtidaiyah in Malang. This research can be categorized as descriptive research. The content analysis research strategy is seen as the right strategy to draw the valid conclusions from a book or document. The results of the research are: 1) The principles of teaching materials applied in the preparation of the books: valid, meaningful, tendency and concern, worthy to be studied and having global principles. 2) The organization of teaching materials applied in the preparation of the books is a logical and psychological organization. 3) The language skills and aspects applied in the preparation of the books are mufrodat, istima ', kalam, qiro'ah, and kitabah. 4) The learning objectives formulated in the books are students' abilities in identifying hijaiyah letter sounds on the material presented, discovering the meaning of oral or written discourse, and being able to have dialogue in Arabic language, and 5) The types of evaluations that are applied in the books are: a) making questions based on the available answers, b) answering questions by choosing the correct answer, c) interpreting mufrodat, d) writing sentences and their meanings, e) composing words to be a perfect sentence, f) translating Indonesian sentences into Arabic, g) translating from Arabic into Indonesian, h) completing empty sentences to be perfect sentences, i) writing Arabic numbers, j) connecting mufrodat which has opposite meaning, and $\mathrm{k}$ ) give harokat to a word.
\end{abstract}

\section{Introduction}

In this advancement era, everything is progressing. Including matters in education such as its textbook, its curriculum, and even its learning and teaching methodology. In this situation, teachers are obligated to update theirs knowledges and abilities to line up with any advancements. One of its is teachers must have the ability to adjust to the material and master it well, because basically, they conveyed other people's ideas to 
students and must be able to understand it. There are two important things of successful second language learning: what goes inside the classroom and what goes on outside of the classroom 1. A textbook is part of those what goes inside and outside of the classroom. Wahab (2013) also said how important it is that textbooks play a prominent role in the teaching learning process as they are the primary agents of conveying knowledge to learners ${ }^{2}$. Textbooks have an important role in the students' achievement ${ }^{3}$. In other words, the existence of teaching material is a determining factor in the success of achieving the curriculum, because teaching material is a part of the curriculum ${ }^{4}$. The curriculum, in the textbook, and the teaching and learning process are one interrelated entity $^{5}$. It means that some basic concepts and skills in the curriculum are contained in textbooks and utilized by teachers in managing teaching and learning activities.

Nowadays, based on the current reseach, shows that the curriculum, textbooks and Arabic language learning of Madrasah Ibtidaiyah are not as expected yet. Since for a long time ago until nowadays, it is always needed as a teacher to make sure that textbook meets their needs of learning. Teaching materials are vital importance to the language teacher, therefore careful evaluation of any materials, particularly coursebook is essential to ensure they meet the requirements of the teachers, learners and the course it self ${ }^{6}$. There are lot of researchs that had been done by other researcher related to textbook analysis. evaluation Based on my searching on several international journal websites such as Springer journal, Oxford Journal, JSTOR journal, Cambridge journal and other international websites there mostly are about textbook analysis in common and aviable specified textbook analysis is about English textbook. Anyhow, there is still a few researchs that can be used as references related to Arabic textbook analysis, especially in scope of international research.

Since there is still a few research that focussed on Arabic textbook analysis, this research is important to be held. This research will give us several information such as

\footnotetext{
$2015,1-18$

${ }^{1}$ J.C Richard, "The Changing Face of Language Learning: Learning Beyond the Classroom," Re,

${ }^{2}$ H Harun dkk., "Concept Based Instruction: Enhancing Grammar Competence in L2 Learners," RELC Journal, 2017, https://doi.org/10.1177/0033688217716505.

3 Maman Suryaman, "Dimensi-Dimensi Kontekstual di Dalam Penulisan Buku Text Pelajaran Bahasa Indonesia,” Jurnal DIKSI 12(2) (2006): 167.

${ }^{4}$ A. B Umairah, Al Manhaj wa Anashir (Kairo: Darul Maarif Kairo, 1991).

${ }^{5}$ S Belen, “Ebtanas, Kurikulum dan Buku Pelajaran BASIS,” Edisi Khusus, 2002.

${ }^{6}$ G.S Steele, "Book Review: Materials Evaluation and Design for Language Teaching, Second EditionMcGrathI.Materials Evaluation and Design for Language Teaching, Second Edition (Edinburgh:
} 
various main angles that become potential which include: 1) Principles for preparing teaching materials, 2) Organization of teaching materials, 3) Language skills 4) Learning objectives and 5) Types of evaluations, which are applied in Arabic textbooks of Madrasah Ibtidaiyah in Malang.

Based on the current researcher's observations on the formal Arabic curriculum of class IV - VI Madrasah Ibtidaiyah, it can be stated several things related to the existence of a formal curriculum that it can be explained that the Arabic material in the fourth grade (which was the first class to be taught Arabic) begins with the title ta'aruf by introducing class / school situations, not family situation as the initial environment known to students, this is contrary to the necessity of the existence of material relations with student experience Abdullah ${ }^{7}$, Thu'aimah ${ }^{8}$ and Mark ${ }^{9}$ Even the title "family" / usroty, is only presented in chapter 5. In class IV of the first chapter "Ta'aruf" students have been introduced to $n a h w u$, whereas good teaching materials should be taught from simple things to complex things ${ }^{10} . N a h w u$ or grammatical is complex things that do not need to be taught at the beginning. Scheffler (2015) also said that it is reasonable to teach language in chunks and put the grammar later as long as not much later because he believes that students are supposed to obtain enough 'suitable input' in the beginning ${ }^{11}$.

Learning four language skills (istima', kalam, qiro'ah and kitabah) has not shown to be well taught, for example, speaking skills (kalam) are still often represented by exercises that require students to interpret, not demand speaking skills directly, even though learning Arabic for non-speakers / foreigners should emphasize four language skills especially for beginner ${ }^{12}$. Ching-Ni Hsieh, Speaking Proficiency of Young Language Students: A discourse-Analytic Study, Tanaman Obat (USA: SAGE, 2017). also stated that the need for a better understanding of young learners' language

Edinburgh University Press, 2016), $344 \quad$ pp,” RELC Journal, 2017,
https://doi.org/10.1177/0033688217701954.

${ }^{7}$ A. S Abdullah, Ta'lim Al Lughah fi Manhaju Tarbiyah At Thufulah Almubarokah Dalil Lil Aba' wal Mualimin (Al Ardan: Syirkah Muthoba' As shofwah Aman Al Ardan, 1997).

${ }^{8}$ R.A Thuaimah, Ta'lim Al Lughah Al Arabiyah li Ghairi Natiqin biha manahijuhu wa asalib (Ribath: Mansyurat Al Munadhomah Al Islamiyah Litarbiyah wal Ulum wa Tsaqofah, 1989).

${ }^{9}$ A.I Markur, Tadris Funun Al Lughah Al Arabiyah (Darul Syuwaf, 1991).

10 Ahmad Syarifuddin, "Analisis Kebutuhan Materi Ajar ' Berbicara Bahasa Arab'Berbasis Pendekatan Komunikatif bagi Pembelajaran Non-Bahasa Arab,” Jurnal Intizar 32(2) (2017): 267.

11 P Scheffler, "Grammar and Lexis: Better Safe than Sorry," Oxford University Press: ELT Journal 69(4) (2015), https://doi.org/10.1093/elt/ccv039.

12 M.K An Naqoh, Ta'lim Al Lughah Al Arabiyah Lin Natiq billughat Ukhra Asasihimadkhaluhu- Thariqu Tadris (Makkah: Universitas Umul Quro, 1985). 
developmental patterns and the linguistic profiles of their language performances has never been greater ${ }^{13}$.

The book used is compiled based on a communicative approach, but the material that has not reflected it. Evidenced by the emergence of tarjamah from the beginning, even in each beginning and middle of the chapter. Whereas, learning with communicative principles emphasizes context, activity ${ }^{14}$. Materials with communicative approach will lead teachers to communicative teaching practices because it has plethora same basic principles. As Miller (2000) said that besides communicative teaching practices involve active students initiave, this also focussed on language use and individual progress ${ }^{15}$. Beetwen the book, the aproaches and teacher, they should be able to blend into one action. It is because as professional, teachers should not only to learn theory and understand why theories are important but also to learn how to aply the theoritical frameworks in practices ${ }^{16}$. Whenever teachers are able to solve the lackness from the book and find appropriate theory or method in teaching material, tt will give great contribution teaching material if the material reflects it properly.

\section{Theoretical Support}

\section{Principles of Preparing Teaching Materials}

Every teacher should be able to prepare their teaching materials. Teachers are material developers that should be able to create and adapt materials for plethora reasons, such as for their own professional development ${ }^{17}$. In case of teaching material, there are several principles that must be considered in the formulation of teaching materials ${ }^{18}$. Nicholas states that among the principles or standards in selecting teaching material are: 1) Valid, that is when the facts displayed are real, authentic and in accordance with scientific truth, moreover their existence is in accordance with the learning objectives , 2) Meaningful (utility), that teaching material have meaning when giving value to student life, 3) tendency and concern, that teaching material is in line with student attention when

13 C.-N Hsieh, Speaking Proficiency of Young Language Students: A discourse-Analytic Study. Tanaman Obat (USA: SAGE, t.t.).

14 Thuaimah, Ta'lim Al Lughah Al Arabiyah li Ghairi Natiqin biha manahijuhu wa asalib.

15 L Miller dan D Aldred, "Student Teachers' Perception About Communicative Language Teaching Methods," RELC Journal 31(1) (2000).

16 Jan Wrenn dan Bruce Wrenn, "Enhacing Learning by Integrating Theory and Practice," International Journal of Teaching and Learning in Higher Education 21(2) (t.t.): 258-65.

${ }^{17}$ M Bouckaert, "Current Perspective on Teachers as Material Developers: Why, What and How?," Netherland : RELC Journal, 2018, 1-18. 
prioritizing student tendencies and interests, 4) Learnability, that teaching materials deserve to be studied when it pays attention to students' abilities, individual differences along with the principles of gradation in their presentation, 5) Global Principles, that teaching material is good when it does not provide geographic boundaries between humans ${ }^{19}$.

\section{Teaching Material Organization}

The contents of teaching materials should be well organized in order to realize competencies as much as possible from the objectives set by the curriculum. There are two types of learning materials organized by experts:

a. Organizations logically, namely paying attention to the order of knowledge as limited as can be accepted by students.

b. Organizations psychologically, meaning the presentation of material that is in accordance with the interests and tendencies of students and specific sides that exist in students ${ }^{20}$.

The material standards of the organization are 3: continuity, improvement Thu'aimah ${ }^{21}$ and Umairah ${ }^{22}$ adding order (sequence).

\section{Language Skills}

Language is an important key in children's thinking and social life. It is an important factor in shaping and building his personality. Moreover, stated that a dimension of language is strongly related to general cognitive skills and academic performance which was supported by his observation that native-speaking children acquire conversational fluency at an early age, while their academic language use develops throughout their schooling and beyond ${ }^{23}$. Especially students who learn Arabic language which Arabic is unique in that proficiency in reading and speaking often require markedly different vocabulary sets ${ }^{24}$. Therefore children must be able to speak in order to succeed in facing life ${ }^{25}$. Among the language learning materials are language

18 Thuaimah, Ta'lim Al Lughah Al Arabiyah li Ghairi Natiqin biha manahijuhu wa asalib.

${ }^{19}$ Umairah, Al Manhaj wa Anashir.

${ }^{20}$ Thuaimah, Ta'lim Al Lughah Al Arabiyah li Ghairi Natiqin biha manahijuhu wa asalib.

21 Thuaimah.

${ }^{22}$ Umairah, Al Manhaj wa Anashir.

23 B Tomlinson, "Testing to learn: a personal view of language testing," ELT Journal 59(1) (2005): 39-46, https://doi.org/10.1093/elt/cci005.

${ }^{24}$ K.M Wahba dan A.Q Chaker, "Arabic Language Learning Textbook: An Evaluation of Current Approaches,” Georgetown University Press : JSTOR Journal 46(2013) (2013): 111-23.

${ }_{25}$ M.S.I.A Al Mujawar, Tadris Al Lughah Al Arabiyah bil Marhalal Al ibtidaiyah Asasihi wa tathbiqihi (Kuwait: Dar Al Qolam wa Nasyar wa Tauzi’, 1974). 
skills consisting of four skills ${ }^{26}$.Four language skills taught to children / beginners in formal institutions include: listening skills (maharah istima '), speaking skills (maharah kalam), reading skills (maharah qira'ah), and writing skills (maharah kitabah). The four skills can be taught separately or integratively.

\section{Learning Objectives}

There are plethora factors that can influence students in learning language. At least, the main problems in learning are how to formulate learning goals and how to realize them. Besides those two main problems, L1 habits also often to interfere with the process of learning a second language which can be their big chalange in learning L2. ${ }^{27}$ Teachers are required to choose smartly the right method to achieve the desired goals. The selection and determination of methods in learning and teaching process based on the strategy, the use of method effectively is an efficient tool to achieve the objective ${ }^{28}$. Because learning is effective when the goal can be achieved with the right time and method. ${ }^{29}$

\section{Evaluation and Training}

Evaluation plays an important role in learning teaching activities. Because the success or the failure of learning can be known through the evaluation results. It also reflects the effectiveness of teaching methods, material, and learners' skill and progress. ${ }^{30}$ Furthermore, through the evaluation of a textbook, teachers know the content of the book, its strengths and weaknesses which will facilitate them to adapt it to suit the course aims, learners' needs and teachers' beliefs (Anjaneyulu, 2014) ${ }^{31}$. Language learning evaluation or exercises and learning activities cannot be separated from one another, both have a close relationship. Because the practice is directed at the material that has been taught, while learning leads to practice. ${ }^{32}$ The test is understood as a tool, procedure or set of activities that are used to obtain an example of a person's behavior that gives an idea of his abilities in a particular field of teaching. Through the test, it is

${ }^{26}$ Umairah, Al Manhaj wa Anashir.

${ }^{27}$ M.F Khan, "Embedded vowels: Remedying the Problems Arising out of Embedded Vowels in the English Writings of Arab Learners," RELC Journal 44(2) (t.t.): 233-51.

28 Samiudin, "Peran metode untuk mencapai tujuan pembelajaran," Jurnal Study Islam 11(2) (2016): 118 .

${ }^{29}$ M.A Al Khuli, Asalib Tadris Al lughah Al Arabiyah (Riyadh: Saudi Arabiyah, 1982). 44(1) (2011).

${ }^{30}$ U Adithepsathit, "Book Review: Designing and Analyzing Language Test," RELC Journal

${ }^{31}$ Anjaneyulu, T. (2014). A critical Analysis of The English Language Textbooks in Andhra Pradesh, India. ELT Research Journal. 3(4). 181-200.

${ }^{32}$ A. I. M Muhammad, Ikhtibarat Al Lughah (Saudi Arabiyah: Jami'ah Malik As Saud, t.t.). 
expected that the information about how much and how profound the abilities of a student has in the field of teaching will be obtained. In language teaching, this kind of test is known as a language test, whose main goal is the level of language proficiency.

Language ability refers to the abilities related to the use of language in everyday real communication. Craword (2004) stated that teachers must themselves be language users and make school domains of language use if students are realistically to become language users in their turn ${ }^{33}$. Moreover, learning is encouraged through the familiarity of the concepts in question as to engage learners in new inquiries that support the process of generating the relevant knowledge within the classroom itself ${ }^{34}$. Language is a tool of communication that help human to deliver or express their thoughts, willingness, and feelings verbally or written ${ }^{35}$. Language skills are concrete and refer to the actual use of language, in oral form that can be heard, or in written form that can be read. All of them are the target of language tests. The main purpose of language testing is to provide opportunities for learning, both for the students who are being tested, and the professionals who are administering the tests (Tomlinson, 2015) ${ }^{36}$. Exercise in the form of test questions as an evaluation tool cannot be underestimated in its preparation, because it must have certain criteria as a good test ${ }^{37}$. These criteria include: validity, reliability, power difference, objectivity, and easy to be applied ${ }^{38}$.

The language skills test in terms of the types of language skills are 4, namely:

1. Listening test

Listening as one of the four language skills, is an ability that allows a person who uses the language to understand it verbally. Therefore, this ability is very important. Without good listening skills, there are many misunderstandings in communication between language users that can cause various obstacles in the implementation of daily tasks and activities.

Listening is basically passive-receptive because the initiative to educate is not from himself first but from others. Mastering listening skills is also related to the sound

\footnotetext{
${ }^{33}$ Crawford, J. (2004). Language Choices in the Foreign Language Classroom: Target Languageor the Learners' First Language?. RELC Journal. 35.1 . 5-20.

${ }^{34}$ Harun, H. Et al. (2017). Concept Based Instruction: Enhacing Grammar Competence in L2 Learners. RELC Journal. 1 -17.

${ }^{35}$ Devianty, Rina. (2017). Bahasa Sebagai Cermin Kebudayaan. Jurnal Tarbiyah, 24(2), 230

${ }^{36}$ Tomlinson, B. (2005). Testing to Learn: A Personal View of Language Testing. ELT Journal. $59 / 1$.

${ }^{37}$ Djiwandono, Soenardi,M. Tes Bahasa dalam Pengajaran. Bandung: ITB,1996

${ }^{38}$ Muhammad, Ikhtibarat Al Lughah.
} 
of the language, namely to distinguish or pronounce each sound appropriately, without having to be accompanied by an understanding of the meaning contained in the words and the expressions expressed. The ability to understand the spoken language is the target of listening test. The understanding of spoken language includes sounds of the language, phonemes, syllables, loose words, phrases and sentences. Several types of listening tests are: answering questions (phrases), answering questions (sentences), formulating main idea of a reading, answering questions, and retelling.

2. Reading test

Reading is a very important activity in the modern world today in order to find out various information. To understand the information in the form of writing, reading activities are needed along with the ability to understand the contents. Like listening, reading relies on language skills that are basically passive-receptive. Because by reading, we receive a variety of new information. The written information to be read and understood can be expressed in various forms of language use, starting from sentences, paragraphs, essays to books. All of them are written messages whose contents and meanings can only be understood by reading, and relying on the ability to analyze the text. The level of reading ability is reflected in the level of understanding of the content, both implicit and explicit. Several types of reading tests: completing a discourse, answering questions, and summarizing the contents of the reading.

3. Speaking Test

Speaking is an important activity in daily life. By talking, someone tries to express their thoughts and feelings to others verbally. Speaking is an activity that is active-productive. Oral messages conveyed through speaking are a collection of various words in accordance with the rules of grammar. Teaching speaking skill emphasizes the content and meaning in delivering the messages verbally according to the level language mastery. Different types of speaking tests: short stories, retelling, and free speech.

4. Writing test

Like speaking, writing also relies on language skills that are active and productive. Both are attempts to express thoughts and feelings of the speaker through language. The message that needs to be expressed through writing can be carefully selected and arranged systematically, so that if it is disclosed in writing, it is easily and correctly understood. Likewise the word selection, the formulation in the form of a discourse can be done in accordance with the rules of language that are appropriate, good 
and correct. Several types of writing tests: telling pictures, making abbreviations, free writing.

\section{Method}

This research can be categorized as descriptive research, which aims to describe "what is" in certain situations ${ }^{39}$. Content analysis research strategy is seen as the right strategy to draw the valid conclusions from a book or document ${ }^{40}$. In addition, content analysis also allows rendering the rich meaning associated with organizational documents combined with powerful quantitative analysis ${ }^{41}$ In this case, in the form of Arabic textbooks of Madrasah Ibtidaiyah. Barcus suggests that content analysis is a study that aims to analyze communication messages scientifically ${ }^{42}$. Holsti provides a definition of content analysis as any technique that is used to draw conclusions by trying to find the characteristics of the messages, which are carried out objectively and systematically. ${ }^{43}$

In accordance with the content analysis component proposed by the content analysis activities in this study consisted of three main steps, namely: First, data formation ${ }^{44}$. The data information is a process consisting of unitization, sample determination, and recording system. Unitization is an activity to dissect the symptoms of concern into separate analysis units. Unitization is based on five main categories (according to the formulation of the problem above). Second, drawing an inference is the most important step in the content analysis because it involves the work validity of this analysis activity. Drawing an inference is a process of how data is related to the context and the underlying standard theory ${ }^{45}$. For these needs, in this study, each category was formulated operationally in accordance with the context and standard theory, as well as the target. The results of the formulation are used as a basis for developing instruments. Third, analysis is an activity to summarize the results of data inference, so that it can

\footnotetext{
39 Razavieh, D. A. L. C. J. A. (1982). Tanpa tabun Pengantar Penelitian dalam Pendidikan Terjemahan Arif Furchan. Surabaya: Usaha Nasional. 415

${ }^{40}$ Lincoln. (1985). Naturalistic Inquiry. Baverly Hill: Sage Publication.

41 Duriau, V. J. Et al. (2007). A Content Analysis of the Content Analysis Literature in Organization Studies: Research Themes, Data Source, and Methodological Refinements. Organization Research Methods. 10 (1).

${ }^{42}$ Holsti, "Content Analysis for the Social Sciences and Humanities," Addison-Wesley, 1969.

${ }^{43}$ [CSL STYLE ERROR: reference with no printed form.].

$44 \mathrm{~K}$ Krippendorf, Content Analysis, An Introduction to Its Methodology (London: Sage Publications, 1980).

${ }^{45}$ Krippendorf.
} 
provide a description of the design of Arabic textbook of Madrasah Ibtidaiyah and is expected to provide an overview of the differences in the quality of textbooks with one another.

\section{Data Sources}

The data sources used in this study were the first main data examined, namely the Textbook used in the Madrasah Ibtidaiyah x with details: 1) Book I: Mughni, Abdul and Uswatun Hasanah. 2009. Mengenal Bahasa Arab.Surabaya. PT Tiga Serangkai Pustaka Mandiri, 2) Buku II : Mughni, Abdul and Uswatun Hasanah.2009. Mengenal Bahasa Arab.Surabaya.PT Tiga Serangkai Pustaka Mandiri, 3) Buku III : Wahyudi,Agus.2010.Aku Cinta Bahasa Arab.Surabaya. PT Tiga Serangkai Pustaka Mandiri and secondary data literature books that contain theories about the curriculum and preparation of teaching materials.

\section{Instruments}

To get the data that is accordance with what was formulated in the formulation of the problem above, an instrument is needed in the form of a check list guideline containing questions based on a theoretical study of the preparation of teaching materials. The items of the instrument were adapted from Rusydi Ahmad Thu'aimah ${ }^{46}$. Because of the consideration of time and effort and financial resources, the researcher did not analyze all the aspects needed, but took some of the basic things to do.

\section{Data Analysis}

Whatever the type of research is, descriptive research in the form of exploratory or developmental methods can be same because the data obtained from the form is same. The different is how to interpret data and draw conclusions. Data obtained from questionnaires or checklists, summed or grouped according to the form of the instrument used.

\section{Result and Discussion}

Book I: in terms of valid principle, all materials (6 chapters) or $100 \%$ material fulfills the principle, as well as the principle of meaningfulness, all materials ( 6 chapters) or $100 \%$ material fulfills the principle, the principle of tendency and concerning, all materials (6 chapters) or $100 \%$ material fulfills the principle, and the principle of learnability, all materials (6 chapters) or $100 \%$ material fulfills that principle, as well as

${ }^{46}$ Thuaimah, Ta'lim Al Lughah Al Arabiyah li Ghairi Natiqin biha manahijuhu wa asalib. 
the global principle, all materials covering 6 chapters or $100 \%$ material fulfills the principle.

Book II: in terms of valid principle, all materials (6 chapters) or $100 \%$ material fulfills the principle, as well as the principle of meaningfulness, all materials (6 chapters) or $100 \%$ material fulfills the principle, the principle of tendency and concerning, all materials (6 chapters) or 100\% material fulfills the principle, and the principle of learnability, all materials (6 chapters) or $100 \%$ material fulfills that principle, as well as the global principle, all materials covering 6 chapters or $100 \%$ material fulfills the principle.

Book III: in terms of valid principle, all materials (6 chapters) or $100 \%$ material fulfills the principle, as well as the principle of meaningfulness, all materials ( 6 chapters) or $100 \%$ material fulfills the principle, the principle of tendency and concerning, all materials (6 chapters) or $100 \%$ material fulfills the principle, and the principle of learnability, all materials (6 chapters) or $100 \%$ material fulfills that principle, as well as the global principle, all materials covering 6 chapters or $100 \%$ material fulfills the principle.

The organization of teaching materials applied in the preparation of Arabic textbooks of Madrasah Ibtidaiyah in Malang is a logical and psychological organization. Logical organizations are applied to "material sequence". The teaching material is coherent, namely the material starts from the simple (easy) to the material that is rather difficult. This is evidenced in volume 1 by introducing ta'aruf material at the beginning, then choosing the material of daily life in the family. In volume 2, it was introduced by material about houses, gardens, schools, libraries, cooperative students that are appropriate with the capacity limits of the students' abilities. While in volume 3, it was introduced by the material taught, namely about time, daily activities, homework and travel. These materials can be understood by students.

The psychological organization applied in volume 1 is the habit of students who like to know one another, so the ta'aruf material needs to be introduced. Students usually want to know more about what they have known, so in this context, Ta'aruf material is given. While in volume 2, the psychological element that can be explained is that the material taught is also related to the interests of students in the time children like to know the surrounding environment. In volume 3, psychological elements are raised through 
material that is very important to be studied by students, namely knowing the time, life, homework and recreation.

In terms of language skills, it includes 4 skills (istima ', kalam, qiro'ah and kitabah) and mufrodat. The material begins with Mufrodat, then the maharah begins with maharah qiro'ah, kalam, istima' and kitabah in sequence. And the other ordered models as needed. Maharah is taught through nadhoriyah wihdah meaning that one theme is taught for four maharoh, not one theme for one maharoh. In terms of material themes, which are taught in volume 1 , it includes

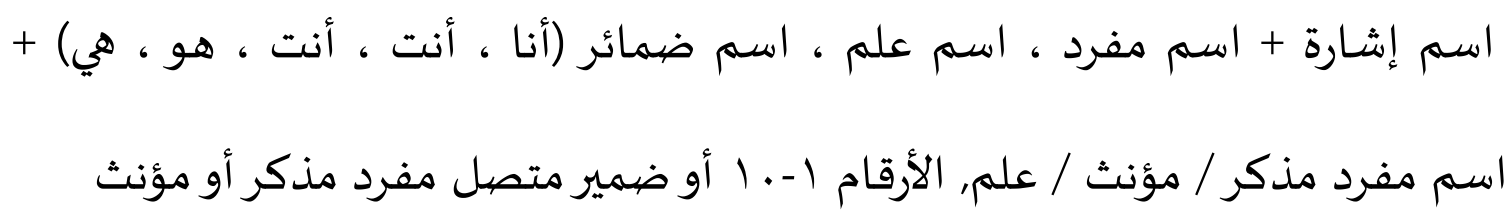

while in volume 2 includes

هذا / هذه + ال + اسم + اسم صيفة, مبتداء + خبر + ظرف أو جار زمجرور او خبر

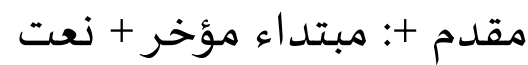

and volume 3 includes

$$
\text { فعل مضارع / فعل أمر + مفعول باه, فعل ماض + فاعل + مفعول باه }
$$

The learning objectives from volume 1 to 3 are: students' ability to memorize and understand Mufrodat, finding meaning or ideas from simple written discourse, writing words, sentences, and arranging words into perfect sentences, and being able to understand written discourse in the form of exposure or dialogue, and being able to communicate in Arabic

The type of evaluation applied in Arabic textbooks of Madrasah Ibtidaiyah in Malang is to make questions based on the available answers, answer questions by choosing the correct answer, interpret mufrodat, write sentences and their meanings, compose words to be perfect sentences, translate Indonesian sentences into Arabic, translate Arabic sentences into Indonesian, complete empty sentences into perfect sentences, write Arabic numbers, connect mufrodat which has opposite meaning, and give harokat to a word. 


\section{Conclusion}

From the description of the results above, it can be concluded that "The characteristics of the Arabic language textbook of Madrasah Ibtidaiyah in Malang" are described in the following: Principles of teaching materials applied in the preparation of textbooks: valid, meaningful, tendency and concern, worthy to be studied and have global principle. The organization of teaching materials applied in the preparation of Arabic textbooks of Madrasah Ibtidaiyah in Malang is a logical and psychological organization. The language skills include 4 skills (istima ', kalam, qiro'ah and kitabah) and mufrodat. The material begins with mufrodat, then the maharah begins with maharah qiro'ah, kalam, istima' and kitabah in sequence. And the other ordered models as needed. Maharah is taught through nadhoriyah wihdah meaning that one theme is taught for 4 maharoh, not one theme for one maharoh. The learning objectives both from volumes 1 to 3 are: the ability of students to memorize and understand Mufrodat, finding meaning or ideas from simple written discourse, writing words, sentences, and arranging words into perfect sentences, and being able to understand written discourse in the form of exposure or dialogue, and being able to communicate in Arabic. And the types of evaluations that are applied in Arabic textbooks of Madrasah Ibtidaiyah in Malang are making questions based on the available answer, answering questions by choosing the correct answer, interpreting mufrodat, writing sentences and their meanings, arranging words into perfect sentences, translating Indonesian sentences to Arabic, translating Arabic sentences into Indonesian sentences, completing empty sentences into perfect sentences, writing Arabic numbers, connecting mufrodat which has opposite meaning, and giving harokat to a word.

\section{References}

Abdullah, A. S. Ta'lim Al Lughah fi Manhaju Tarbiyah At Thufulah Almubarokah Dalil Lil Aba' wal Mualimin. Al Ardan: Syirkah Muthoba' As shofwah Aman Al Ardan, 1997. Adithepsathit, U. "Book Review: Designing and Analyzing Language Test." RELC Journal 44(1) (2011).

Al Khuli, M.A. Asalib Tadris Al lughah Al Arabiyah. Riyadh: Saudi Arabiyah, 1982.

Al Mujawar, M.S.I.A. Tadris Al Lughah Al Arabiyah bil Marhalal Al ibtidaiyah Asasihi wa tathbiqihi. Kuwait: Dar Al Qolam wa Nasyar wa Tauzi’, 1974. 
An Naqoh, M.K. Ta'lim Al Lughah Al Arabiyah Lin Natiq billughat Ukhra Asasihimadkhaluhu- Thariqu Tadris. Makkah: Universitas Umul Quro, 1985.

Belen, S. “Ebtanas, Kurikulum dan Buku Pelajaran BASIS.” Edisi Khusus, 2002.

Bouckaert, M. "Current Perspective on Teachers as Material Developers: Why, What and How?" Netherland: RELC Journal, 2018, 1-18.

Harun, H, N Abdullah, N Ab Wahab, dan N Zainuddin. "Concept Based Instruction: Enhancing Grammar Competence in L2 Learners.” RELC Journal, 2017. https://doi.org/10.1177/0033688217716505.

Holsti. "Content Analysis for the Social Sciences and Humanities." Addison-Wesley, 1969.

Hsieh, Ching-Ni. Speaking Proficiency of Young Language Students: A discourseAnalytic Study. Tanaman Obat. USA: SAGE, 2017.

Hsieh, C.-N. Speaking Proficiency of Young Language Students: A discourse-Analytic Study. Tanaman Obat. USA: SAGE, t.t.

Khan, M.F. "Embedded vowels: Remedying the Problems Arising out of Embedded Vowels in the English Writings of Arab Learners.” RELC Journal 44(2) (t.t.): 233-51.

Krippendorf, K. Content Analysis, An Introduction to Its Methodology. London: Sage Publications, 1980.

Markur, A.I. Tadris Funun Al Lughah Al Arabiyah. Darul Syuwaf, 1991.

Miller, L, dan D Aldred. "Student Teachers' Perception About Communicative Language Teaching Methods.” RELC Journal 31(1) (2000).

Muhammad, A. I. M. Ikhtibarat Al Lughah. Saudi Arabiyah: Jami'ah Malik As Saud, t.t. Richard, J.C. "The Changing Face of Language Learning: Learning Beyond the Classroom." Re, 2015, 1-18.

Samiudin. "Peran metode untuk mencapai tujuan pembelajaran." Jurnal Study Islam 11(2) (2016): 118.

Scheffler, P. "Grammar and Lexis: Better Safe than Sorry." Oxford University Press: ELT Journal 69(4) (2015). https://doi.org/10.1093/elt/ccv039.

Steele, G.S. "Book Review: Materials Evaluation and Design for Language Teaching, Second EditionMcGrathI.Materials Evaluation and Design for Language Teaching, Second Edition (Edinburgh: Edinburgh University Press, 2016), 344 pp.” RELC Journal, 2017. https://doi.org/10.1177/0033688217701954. 
Suryaman, Maman. "Dimensi-Dimensi Kontekstual di Dalam Penulisan Buku Text Pelajaran Bahasa Indonesia.” Jurnal DIKSI 12(2) (2006): 167.

Syarifuddin, Ahmad. “Analisis Kebutuhan Materi Ajar ' Berbicara Bahasa Arab’Berbasis Pendekatan Komunikatif bagi Pembelajaran Non-Bahasa Arab.” Jurnal Intizar 32(2) (2017): 267.

Thuaimah, R.A. Ta'lim Al Lughah Al Arabiyah li Ghairi Natiqin biha manahijuhu wa asalib. Ribath: Mansyurat Al Munadhomah Al Islamiyah Litarbiyah wal Ulum wa Tsaqofah, 1989.

Tomlinson, B. “Testing to learn: a personal view of language testing.” ELT Journal 59(1) (2005): 39-46. https://doi.org/10.1093/elt/cci005.

Umairah, A. B. Al Manhaj wa Anashir. Kairo: Darul Maarif Kairo, 1991.

Wahba, K.M, dan A.Q Chaker. “Arabic Language Learning Textbook: An Evaluation of Current Approaches." Georgetown University Press : JSTOR Journal 46(2013) (2013): $111-23$.

Wrenn, Jan, dan Bruce Wrenn. "Enhacing Learning by Integrating Theory and Practice." International Journal of Teaching and Learning in Higher Education 21(2) (t.t.): 25865. 